DOI https://doi.org/10.18551/rjoas.2017-06.26

\title{
EFFECT OF SHARED LEADERSHIP, ENTREPRENEURSHIP ORIENTATION ON MEETINGS, INCENTIVES, CONFERENCES, EXHIBITION (MICE) PERFORMANCE IN JAKARTA
}

\author{
Iqbal Alan Abdullah \\ Doctoral Program of Management Sciences, University of Brawijaya, Indonesia
}

Armanu, Setiawan Margono, Djumahir

Faculty of Economics and Business, University of Brawijaya, Indonesia

*E-mail: iqbalalan3@gmail.com

\begin{abstract}
The purpose of this study is to measure and explain how shared leadership can improve MICE business performance in Jakarta. In addition, want to know also whether shared leadership is able to manage entrepreneurship in support of business performance. The research method used a quantitative approach. Data obtained from questionnaires distributed to 140 respondents with the category manager / supervisor representing 7 (seven) companies engaged in the field of MICE in Jakarta. Data analysis techniques were made using Warp Partial Least Square software. The reason for this PLS Warp is because this software is able to generate powerful output data. The results show that shared leadership significant effect on the MICE business performance. Shared leadership too can improve entrepreneurship which ultimately can improve MICE business performance in Jakarta.
\end{abstract}

\section{KEY WORDS}

Shared leadership, entrepreneurship, MICE, business performance.

Indonesia is a country whose position is flanked by two continents of Asia and Australia consists of thousands of islands stretching from Sabang to Merouke. This geography aspect is God's grace given to the people of Indonesia and also as a valuable asset for the development of tourism in Indonesia. One element of Indonesian tourism is the MICE Industry (Meeting, Incentives, Conferences, Exhibition) whose development has not grown well. MICE service business performance is one of the fastest growing and highly important tourism sectors (Seebaluck, et al., 2013).

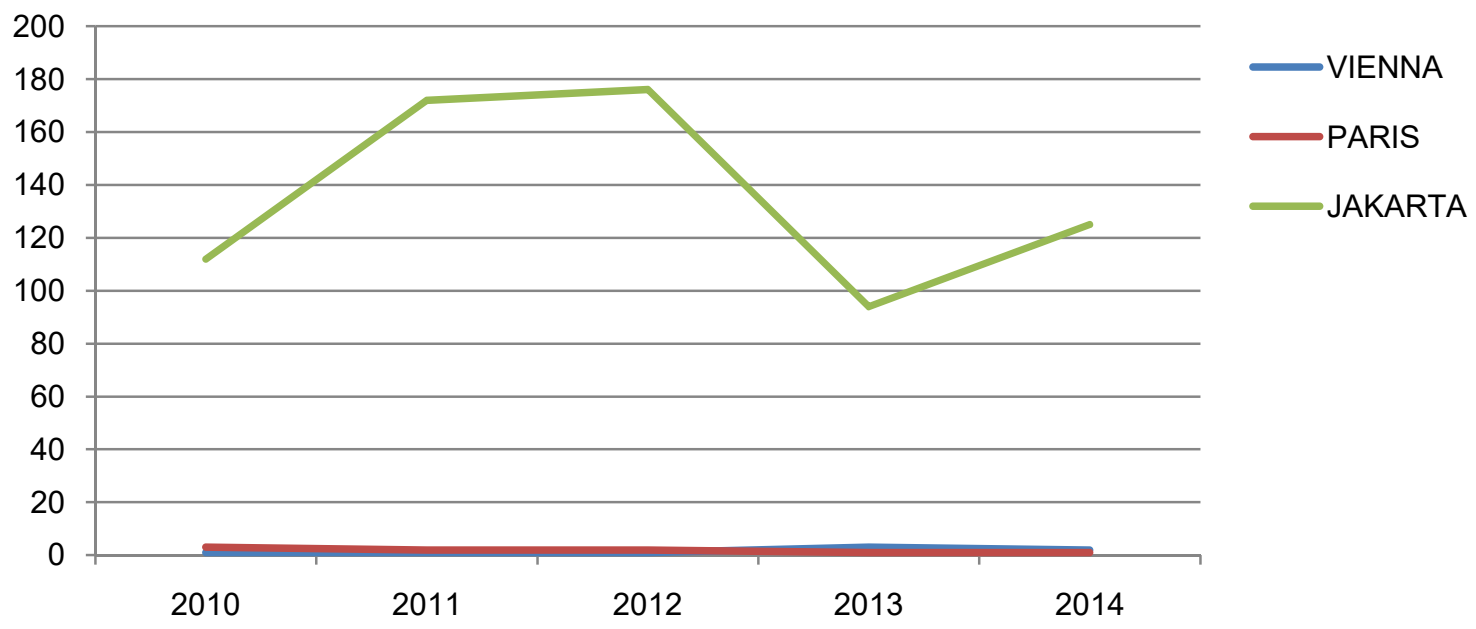

Source: International Congress \& Convention Association, 2014

Figure 1 - Graph of MICE Ranking in the World 
The development of the MICE services business in Jakarta in 2010 was ranked 112th, in 2011 it was ranked 172th. In 2012 it was again ranked 176. In 2013 it rose to the order of 94, and in 2014 fell Again in the order of 125. For more details the development of MICE in Jakarta when compared with the City of Vienna and Paris, can be illustrated with graphs as seen from Figure 1. Similarly, about the phenomenon that occurs in Asean occupies rank 74 as presented in Figure 2.

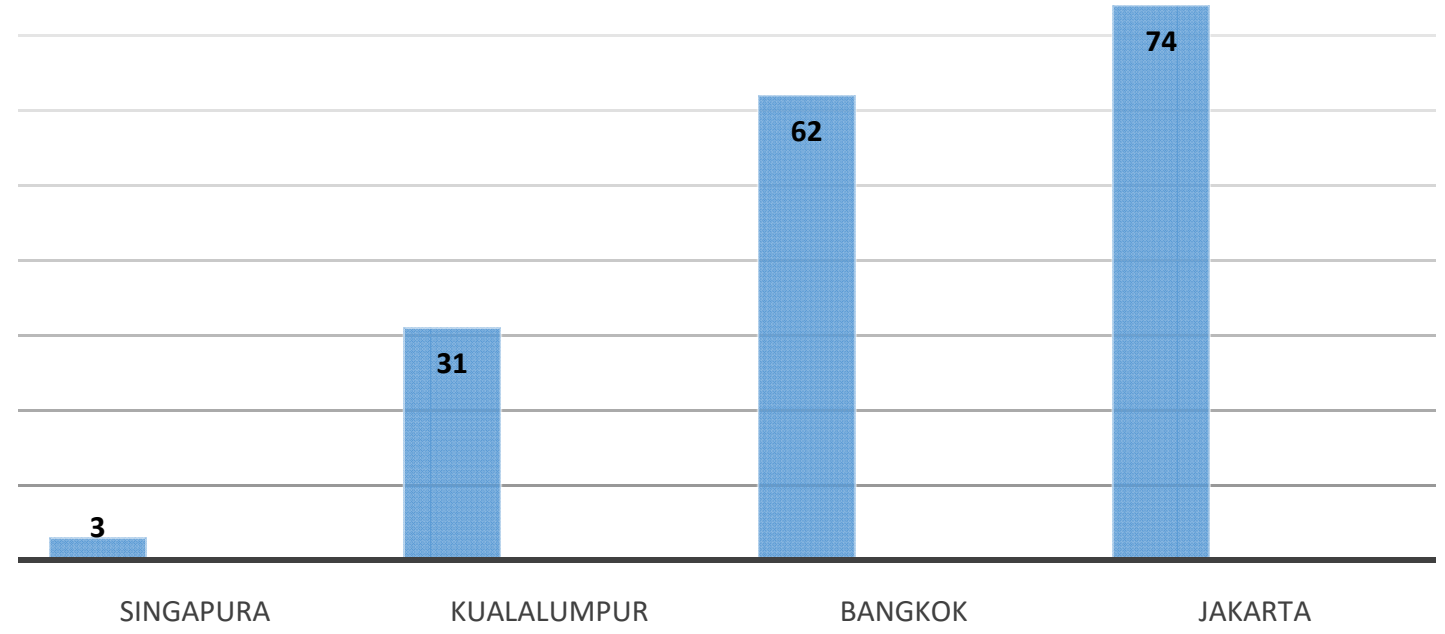

Source: World Economic Forum, 2015

Figure 2 - MICE Graph in Asean, 2015

Factors that make MICE Business performance in Jakarta lagging behind in regional and international are based on limited human resources on MICE and negative issues related to security situation in Jakarta (Warta Kota, 2015).Some solutions to improve company performance can be seen in the literature of Shared Leadership is very important in modern times because it is always focused and effective in improving company performance (Carson, et al., 2007).

Shared Leadership can provide a competitive advantage through organizational resources to assume complex tasks, ultimately improving company performance (Jackson and Denisi, 2003). The solution to organizational problem solving is the practice of Shared Leadership as it is very interesting and always identifies the potential of all members of the organization to work effectively and efficiently (Spisak. et al., 2015).

Zhou (2013) states that entrepreneurship is very important for the development of business today and the future. Shared Leadership and entrepreneurship are important concepts in academic research (Hunt \& Dodge, 2000; Hitt\& Ireland, 2000; Colbert, 2003). The study of entrepreneurial concepts associated with improving company performance has been disclosed by Wiklund\& Shepherd (2005) that entrepreneurship orientation can improve business performance. Studies on Shared Leadership show mixed results.

In a study by Carte et al. (2006) that Shared Leadership does not improve the company's performance, but Boardman (2001) observed that Shared Leadership in Tasmania can improve company performance. Shared Leadership is very effective in improving company performance (Sally 2002). But O'Toole et al. (2002) observes that research on Shared Leadership is said to be ineffective in improving business performance.

Thus the research on shared leadership on business performance is inconsistent. Therefore, the researchers add entrepreneurial variables to support shared leadership can improve the performance of MICE in Jakarta. The purpose of this study is to know and measure the extent to which the influence of shared leadership on the performance of MICE Enterprises in Jakarta and whether shared leadership is able to utilize its entrepreneurship to improve its performance. 


\section{LITERATURE REVIEW}

The MICE Business Performance Concept. The performance of a company is the productivity of a company in which there is a diversity of cultures and characteristics of its members, but has the same vision for achieving company goals (Richard, 2000; Richard, et al., 2003). With the diversity of characteristics and cultures within a company, the role of leadership sharing is important in bringing together a better corporate mission (Rosen, 1999). The importance of leadership and organizational strategy for realizing diversity in enhancing a resource oriented to competitive advantage (Richard, 2000). The company's reputation will increase if diversity can be controlled and manifested by sharing leadership so that the company runs in accordance with the company's goals (besides the company's performance always requires an entrepreneurial orientation to sustain whenever performance Companies face uncertain economic challenges (Frink et al., 2003).

Entrepreneurships Orientation Concept. Peter F. Drucker (1996) says that entrepreneurship is the ability to create new and different. Entrepreneurship is the process of creating something different to generate value by devoting time and effort, followed by the use of money, physical, risks, and then generate remuneration in the form of money and the satisfaction and personal freedom. Meanwhile, Robbins \& Coulter (2007) suggest that entrepreneurship is the process whereby an individual or a group of individuals uses organized Efforts and means to pursue opportunities to create value and grow by fulfilling wants and need Yusof, Permula, and Pangil (2005) that there are four reasons why entrepreneurs is important in society, namely: to leverage factors produce such as land, capital, technology, information and a variety of human resources in producing effective tasks. Identifying opportunities in the environment by increasing the activity that will provide benefits to every person. To choose the best approach in the utilization of all factors of production in order to minimize waste in various entrepreneurial activities. For the benefit of future generations rough innovation and uniqueness, no matter what resources are currently controlled.

Shared Leadership Concept. Carson et al (2007) defines that share leadership is work together between leader and following. Worley \& Lawler (2006) shows three advantages of shared leadership. First, spread knowledge, power, allowing a fast response organization. Secondly, with the approach of sharing, members can develop leadership and management skills through strategy, create value and other tasks in the organization. Third, leaders at different levels who have a grasp on the internal organization of the external environment is seen as an important trend to change the company.

White \& Smith (2010) stated that the share leadership may be superior in improving the business performance. Several studies have shown a significant relationship between shared leadership and business performance. (Pearce \& Barkus, 2004; Hiller, Day \& Vance, 2006; Ishikawa (2012); Small \& Rentsch (2010) Greenberg-Walt and Robertson (2001) described the share leadership is integrate of CEO should really work well.

Otherwise it will be difficult to improve performance. Holmberg and Söderlind (2004) suggest that share leadership is power and reliability together will can success in organization. Shared leadership is collective leadership and collaborative decision-making and have a sense of responsibility for improving performance (Hoch \&Dulebohn, 2013; Sivasubramaniam, Murray, Avolio\& Jung, 2002). Shared leadership is collective influence of the members share with each other in a team. To achieve an organization, leadership must interact and dynamic in improving the performance (Pearce \& Conger, 2003).

\section{METHODS OF RESEARCH}

Companies included in this research are companies engaged in MICE located in the Province of Jakarta. MICE is a large business company oriented to meetings, incentives, conferences, exhibition (MICE). The perpetrators of MICE in Jakarta such as PT. RoyalindoExpoduta; PT. Pacto Convex; PT Tarsus Indonesia; Convex Panorama; PT. Team Asia tama; PT. Even Pro Asia; Even Overlay. 
The main task of the company is to serve the tourists from abroad, and domestic tourists who want to hold meetings, conferences, travel tours and other events such as the implementation of music and exhibitions. This research was conducted in DKI Jakarta province.

This research was started from several phenomena related to MICE performance in Jakarta where this business is less competitive compared to other cities in ASEAN countries such as Singapore, Kuala Lumpur, and Bangkok. From the phenomenon can be drawn red thread that the cause is leadership and entrepreneurial orientation.

Data Collection Method. Data collected through primary data is the distribution of questionnaires to managers and supervisors scattered in seven MICE companies in Jakarta, while secondary data consists of documents and regulations in the field of tourism MICE. The population is 140 people with manager and supervisor capacity at 7 (seven) MICE companies in Jakarta. The sampling technique is a saturated sample where the population is sampled (Sugiono, 2009).

Data Analysis Technique. Descriptive analysis is used to determine the respondent's description of indicators every research variables. A description of each indicator is expressed in the value of the frequency and average values. Picture obtained respondents' perceptions of the indicators in reflecting a variable. Descriptive analysis was also intended to describe the tendency of respondents to the indicator statement relating to the research variables.

To test the hypothesis and build a model worthy (fit), this study uses data analysis methods warp PLS (Partial Least Square) software. This study aims to examine and analyze the causal relationship between exogenous and endogenous variables simultaneously check the validity and reliability of research instrument as a whole. Warp PLS techniques used to have powerful reasons to confirm the theory of the relationship between variables contained in the structural model. Analysis of mediating variables can be done through two approaches, differences in coefficients and multiplication coefficient.

Approach coefficient differences using the screening method to perform analysis with and without the involvement of mediating variables. Method of examination by means of two analyzes, the analysis involves mediating variables and analysis without involving the mediating variables.

Inspection methods mediating variables approach coefficient differences is done as follows: (a) examine the direct influence of Independent Variables on Dependent Variables in the model involving mediating variables, (b) examine the influence of Independent Variables on Dependent Variables on models without involving the mediating variables, (c) Independent variables examined the influence of the variable Mediation, and (d) examine the effect of mediation on variable Dependent variable (Solimun, 2011).

\section{RESULTS AND DISCUSSION}

Description of Respondents by Age, gender and education, length of work. At this table will be explained in detail about the picture on gender, age, level of education, length of work so that the data collected can be grouped according to the number and percentage. The composition of the actors in the MICE business is dominated by men, based on the information that in conducting national and international events did not know when the job is done day and night.

Meanwhile, women as a minority is also in line with the findings Pulkinnen (1996) that women are generally docile, passive and prefer the family. Characters are owned by women are less suited to managing the MICE business in an increasingly competitive global competition. Therefore, the company MICE Services business is dominated by men as much as $75 \%$ and $25 \%$ of women.

It is generally known to correlate education with the knowledge and behavior of people so that the higher the level of education a person then the knowledge will be more extensive and more effective behavior. This also applies in managing this MICE business. MICE business leaders who have a relatively high level of education will manage the business 
effectively, according to careful planning so that it can carry out activities both nationally and internationally.

Based on Table 1, it shows that the level of education the entrepreneurs' MICE is generally output School of Tourism Diploma IV finished 70 percent, while the level of undergraduate education is the education level minority of 10 percent, however, with the number of minimal expected that they can protect not yet scholar. Based on interviews with the respondents they do not continue their education because of busy business. The entrepreneurs generally are relatively aged over 40 years so think continuing education is not something that is important. The details can be seen in Figure 3.

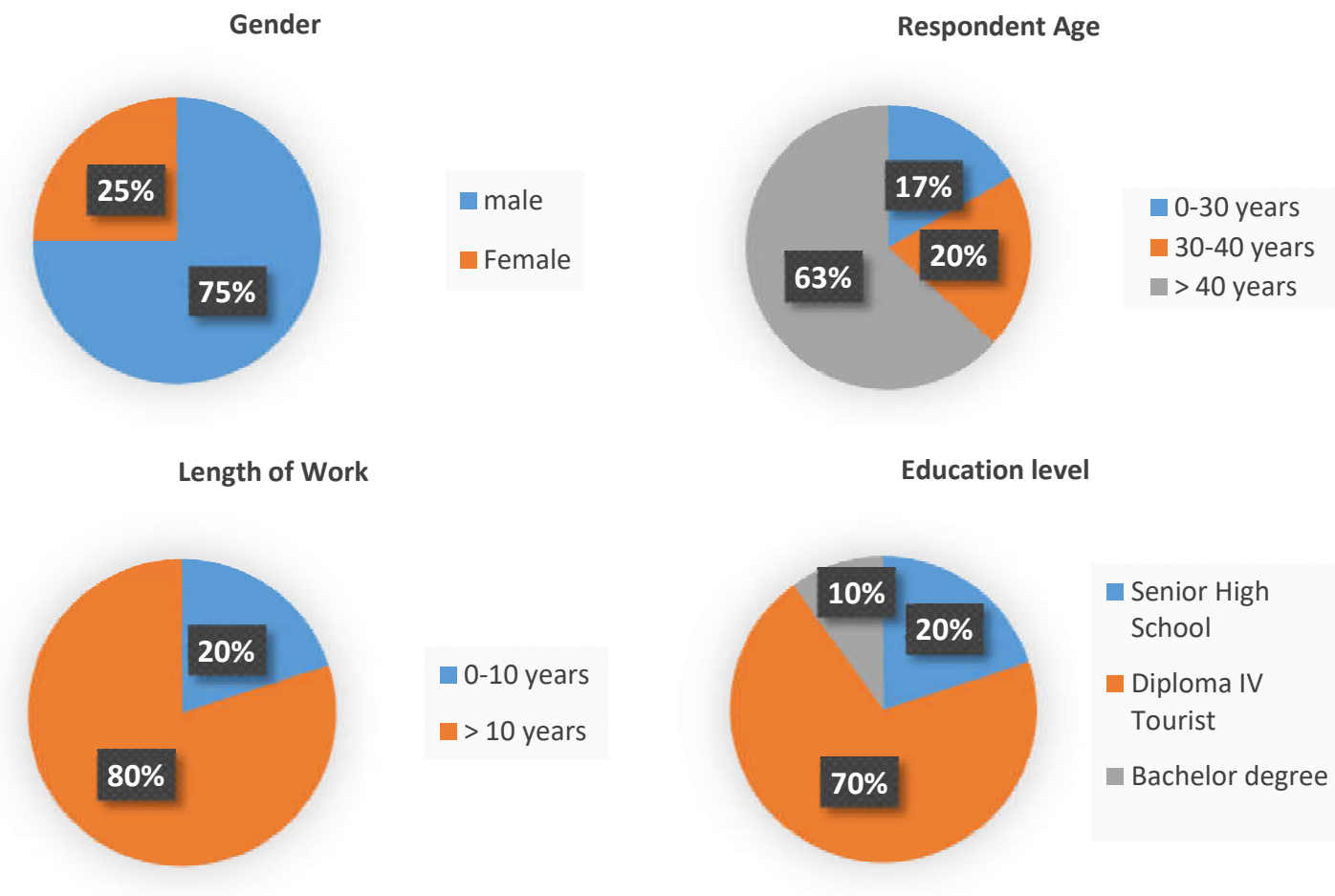

Source: Research Result, 2016

Figure 3 - Characteristics of Respondents

In Berry's previous study in Matsumoto, (1996) found that, male superiority in certain spatial is found in a strict or relatively homogeneous culture, agriculture, while spatial women are commonly found in open, nomadic cultures and gathering and gathering societies. In that culture, the roles given to men and women apply relatively flexibly, as members of a culture form variations of tasks related to group survival.

Based on the opinion Goolsby (1992) explains that the longer the employment of employees, the employee has more experience that has the ability to solve problems that occur in the work environment. From these opinions can be concluded that MICE employees can be categorized as a reliable employee and able to handle problems and jobs that come sudden and urgent. Looking at the level of education respondents can be concluded that most respondents have special education level special for tourism but undergraduate educated respondents (S1) is still not much. The more highly educated employees the employee can overcome the problem of work and also problems in the work environment.

Description of Respondents. Table 2 shows the scores of Respondents' answers on Shared Leadership, entrepreneurial orientation and MICE Business Performance.

The average yield of respondents as in Table 2 above that most indicators reflect leadership role in sharing is an indicator of "self-development» at 4.10 this indicates that the development of self-appreciated by the respondents. According to their personal 
development is very important because it should encourage shared leadership team to add insight, his education and encourage the mastery of information technology.

Table 2 - Scores of Respondents' Answers

\begin{tabular}{|c|c|c|c|c|c|c|c|c|c|c|c|}
\hline \multirow{3}{*}{ Variable / Indicator/ Item } & \multicolumn{10}{|c|}{ Respondents Score } & \multirow{3}{*}{ Means } \\
\hline & \multicolumn{2}{|c|}{ STS } & \multicolumn{2}{|c|}{ TS } & \multicolumn{2}{|c|}{$\mathrm{N}$} & \multicolumn{2}{|c|}{ ST } & \multicolumn{2}{|c|}{ SS } & \\
\hline & $f$ & $\%$ & $f$ & $\%$ & $f$ & $\%$ & $f$ & $\%$ & $f$ & $\%$ & \\
\hline SHARED LEADERSHIP & \multicolumn{10}{|c|}{-} & - \\
\hline Empowerment & \multicolumn{10}{|c|}{-} & 3,89 \\
\hline $\mathrm{X} 1.1$ & 4 & 2,3 & 3 & 1.8 & 27 & 15,8 & 70 & 59,1 & 36 & 21,1 & 3.95 \\
\hline $\mathrm{X} 1.2$ & 4 & 2,3 & - & - & 37 & 21,6 & 78 & 63,7 & 21 & 12,3 & 3.84 \\
\hline Seek Opportunities & \multicolumn{10}{|c|}{$-\infty$} & 3.91 \\
\hline $\mathrm{X} 1.3$ & 3 & 1,8 & 5 & 2,9 & 26 & 15,2 & 69 & 58,5 & 37 & 21,6 & 3.95 \\
\hline $\mathrm{X} 1.4$ & 4 & 2,3 & 6 & 3,5 & 28 & 16,4 & 72 & 60,2 & 30 & 17,5 & 3.87 \\
\hline Self-Development & \multicolumn{10}{|c|}{ 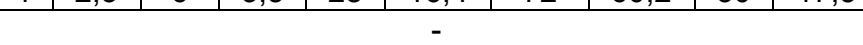 } & 3.99 \\
\hline $\mathrm{X} 1.5$ & 3 & 1,8 & 1 & 0,6 & 18 & 10,5 & 68 & 57,9 & 50 & 29,3 & 4,13 \\
\hline $\mathrm{X} 1.6$ & 2 & 1,2 & 1 & 0,6 & 23 & 13,5 & 57 & 51,5 & 57 & 33,4 & 4,16 \\
\hline $\mathrm{X} 1.7$ & & & 1 & 0,6 & 38 & 22,2 & 59 & 52,6 & 40 & 23,4 & 4,02 \\
\hline Cooperation & & & & & & & & & & & 4.10 \\
\hline $\mathrm{X} 1.8$ & 1 & 0,6 & 1 & 0,6 & 22 & 12,9 & 73 & 60,8 & 43 & 25,2 & 4.11 \\
\hline $\mathrm{X} 1.9$ & & & 3 & 1,8 & 29 & 17,0 & 70 & 59,1 & 38 & 22,3 & 4,03 \\
\hline ENTREPRENEURS ORIENTATION & \multirow{2}{*}{\multicolumn{10}{|c|}{$\begin{array}{l} \\
-\end{array}$}} & 3.88 \\
\hline Dare To Take Risks & & & & & & & & & & & 3.61 \\
\hline OK.1 & 1 & 0,6 & 24 & 1,2 & 79 & 34,1 & 82 & 54,5 & 38 & 9,6 & 3.63 \\
\hline OK.2 & & & 28 & 3,6 & 74 & 31,1 & 100 & 60,5 & 30 & 4,8 & 3,60 \\
\hline New innovation & & & & & & & & & & & 3.55 \\
\hline OK.3 & & & 28 & 3,6 & 88 & 39,5 & 74 & 49,7 & 37 & 7,2 & 3,59 \\
\hline OK.4 & & & 28 & 3,6 & 88 & 39,5 & 74 & 49,7 & 34 & 6,2 & 3,55 \\
\hline OK.5 & & & 27 & 3,0 & 78 & 33,5 & 86 & 56,9 & 33 & 6,6 & 3,61 \\
\hline BUSINESS PERFORMANCE & \multicolumn{10}{|c|}{ MEAN ENTREPRENEUR ORIENTATION } & 3.59 \\
\hline Quality & \multicolumn{10}{|c|}{-} & 3.41 \\
\hline KU1 & & & 27 & 3,0 & 72 & 29,9 & 93 & 61,1 & 32 & 6,0 & 3.63 \\
\hline KU2 & & & 24 & 1,2 & 77 & 32,9 & 98 & 64,1 & 25 & 1,8 & 3,19 \\
\hline Quantity & & 3.60 \\
\hline KU3 & & & 27 & 3,0 & 59 & 22,2 & 103 & 67,1 & 35 & 7,8 & 3,70 \\
\hline KU4 & & & 26 & 2,4 & 68 & 25,1 & 106 & 68,9 & 28 & 3,6 & 4.00 \\
\hline KU5 & & & 23 & 0,6 & 62 & 24,0 & 106 & 68,9 & 33 & 6,6 & 3,10 \\
\hline \multicolumn{11}{|c|}{ MEAN BUSINESS PERFORMANCE } & 3,52 \\
\hline
\end{tabular}

Source: Research Result, 2016.

Indicators that reflect a lesser role in shared leadership is "empowerment» mean that the MICE sector is less likely to get special attention from various parties. In fact, every event has the potential to be developed, so that empowerment is an effort to build the power to encourage, motivate and raise awareness of the potential of the MICE Indonesia as well as to develop it.

Indicators whose role reflects the entrepreneurship orientation maintain quality (OK5). The quality of a very large influence on the activities of the company in order to achieve the goals that have been set. Indicators that reflect a lesser role in Entrepreneurship Orientation is to increase creativity. Creativity is a mental process that involves the appearance of an idea or draft (concept) new, or new connections between existing ideas.

Perceptions of respondents associated with the item «improving corporate profits» now occupies the position of greatest (4.00) for the MICE entrepreneurs want that MICE is a business. Indicators are not many reflection MICE business performance is an indicator of «Keeping the promise» Responder against this indicator has a mean value of 3.10 indicates that promise is a debt that they lack appreciation

Comparison between the load factor and average valuesю This section describes the profile between the variable that contains the comparison between the load factors to an average value, is presented in Table 3 as follows. 
Table 3 - The load factor comparison with the average value

\begin{tabular}{|c|c|c|c|}
\hline No & Variable / Indicator & Loading factor & Means \\
\hline \multicolumn{4}{|c|}{ Shared Leadership } \\
\hline 1 & X1.1 Empowerment & 0,726 & 3.89 \\
\hline 2 & X1.2 Seek Opportunity & 0.760 & 3.91 \\
\hline 3 & X1.3 Self Development & 0.619 & 3.99 \\
\hline 4 & X1.4 Corporation & 0.591 & 4.10 \\
\hline \multicolumn{4}{|c|}{ Entrepreneurship Orientation } \\
\hline 7 & Y2.1 Dare To Take Risks & 0.801 & 3.61 \\
\hline 8 & Y2.2 New Innovation & 0.802 & 3.55 \\
\hline \multicolumn{4}{|c|}{ MICE Business Performance } \\
\hline 9 & Y3.1 quality & 0.701 & 3.41 \\
\hline 10 & Y3.2 quantity & 0.801 & 3.60 \\
\hline
\end{tabular}

Source: Research Result, 2016.

Based on Table 3 above that the highest indicator in reflecting the shared leadership is an indicator of «look for opportunities» to have a charge factor of 0.760 or $76 \%$. The respondents consider that seek opportunities is important for the company in the field of MICE. But in reality, these expectations are not met because the empirical mean value of this indicator cannot be said to be good (3.91) is still below the number four. 3.91 Figures indicate many respondents who disagree and neutral to the indicator seek these opportunities.

The lowest indicator in reflecting the shared leadership is an indicator of cooperation has a value of 0.591 or load factor of $59.1 \%$. The respondents consider that cooperation very important. But some say no empirically what was expected by the majority of respondents related to the cooperation received good appreciation. Their mean value having four or more numbers (4.10).

Indicators that have a high value in reflecting the entrepreneurial orientation is an indicator of new innovations and value load factor of 0802 or $80 \%$. The result of factor loadings is pretty high expectations on this indicator. The lowest indicator in reflecting the entrepreneurial orientation is indicator courage to take risks with the value of load factor of 0801 or $80 \%$.

Courage to take risks according to respondents is absolutely necessary and very important for the development of entrepreneurial orientation. But in reality this indicator did not get a good average value of the respondents (3.61) means that there are still many who disagree and neutral of respondents.

The highest indicator in reflecting the variable MICE business performance is an indicator of the quantity. Quantity in performance is the amount of work performed by a person of employees in a given period. But in reality is not quite good because their mean value is still below the number four (3.60).

Indicators of the lowest in the MICE business performance reflects the value of the content is the quality factor of 0701 or $70 \%$.but in practice is not yet good because the average value of this indicator is below the lift four (3.41). This indicates that respondents are still many who disagree have even stated strongly disagree and neutral against indicators.

Hypothesis Test Result. The hypothesis test result is meant to answer the questions related the relationship among variables that consists of shared leadership, entrepreneurship orientation, and MICE business performance variables. The hypothesis test result is presented in Table 4.

Table 4 - Result of Inner Weight

\begin{tabular}{|l|l|l|l|}
\hline \multicolumn{1}{|c|}{ Variable relationship } & Coefficient & P Values & \multicolumn{1}{c|}{ Information } \\
\hline Shared leadership ->Business Performance & 0.133 & 0.038 & Significant \\
\hline Shared leadership $\rightarrow$ entrepreneurship orientation & 0.413 & 0.001 & Significant \\
\hline Entrepreneurship Orientation->Business Performance & 0.593 & 0.001 & Significant \\
\hline
\end{tabular}

Source: Research Result, 2016. 
The first hypothesis proposed in the conceptual framework chapter states that «Shared Leadership significantly influences on the MICE business performance». The result of the calculation that apparently shared leadership have a significant effect on the business performance with a path coefficient of 0.133 and $p=0.038$. Given $p$ less than 0.05 then it is said to be significant, so the hypothesis is accepted. Path coefficient is positive $(0.130)$ indicates that the better the leadership shared the growing MICE business performance.

The second hypothesis states that the Shared Leadership has significant effect on Entrepreneurship Orientation. The results showed that the shared leadership have significantly influence on entrepreneurial orientation with path coefficient of 0.413 and $p=0.001$. Given $p$ less than 0.05 then it is said to be significant. Marked lane positive coefficient (0.413) indicates that the better the shared leadership, then the better the entrepreneurial orientation.

The third hypothesis states that entrepreneurial orientation significantly influence on the MICE business performance. The result of calculation shows that the entrepreneurial orientation significantly influence the MICE business performance with a coefficient of 0.593 lines and $p=0.001$. Given $p$ less than 0.05 then it is said to be significant. Marked lane positive coefficient $(0.593)$ indicates that the better the entrepreneurial orientation, then increasing the MICE business performance services.

Table 5 - Mediation Test

\begin{tabular}{|c|c|c|c|}
\hline Variable relationship & Coefficient & P Values & Information \\
\hline Shared Leadership -> MICE Business Performance & 0,245 & 0,001 & Weakly significant \\
\hline
\end{tabular}

Path coefficient indirect effect Shared Leadership $(X)$ on the MICE business performance through entrepreneurial orientation amounted to $0.245, p=p$ less than 0.10 , then said weakly significant, so that the entrepreneurial orientation is mediation.

Table 6 - Effect of Total

\begin{tabular}{|c|c|c|c|}
\hline Variable relationship & Coefficient & P Values & Information \\
\hline Shared Leadership -> MICE Business Performance & 0,378 & 0,001 & $(0,378)^{2} \times 100 \%=14,28 \%$ \\
\hline
\end{tabular}

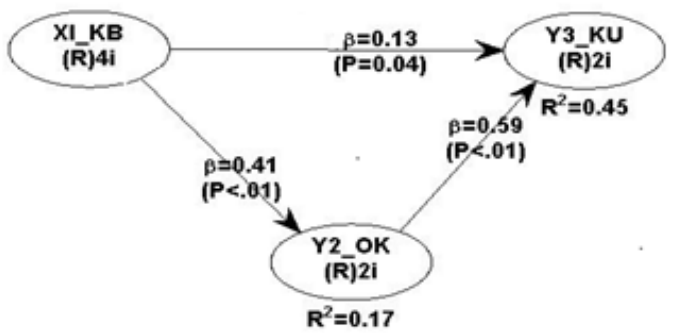

Figure 4 - Research Model

From Table 6 above, can be explained much influence total of a latent variable exogenous to endogenous latent variables. The total effect on entrepreneurial orientation that is equal to 0.378 or $14.28 \%$. This means that the entrepreneurial orientation of latent variables provide a major contribution in influencing the MICE business performance in Jakarta. Further research model can be presented in Figure 4.

\section{CONCLUSION}

Based on the formulation of the problem, research objectives, hypothesis testing and discussion, can be summed up as follows:

Shared Leadership formed of empowerment indicators, looking for opportunities, selfdevelopment and co-operation related to MICE business performance in Jakarta.

Shared Leadership can be directly linked with the entrepreneurial orientation as reflected by the courage to take risks and new innovations.

Orientation entrepreneurship can improve the MICE business performance in Jakarta. 


\section{REFERENCES}

1. Carson, J. B., Tesluk, P. E., \& Marrone, J. A. (2007). Shared leadership in teams: An investigation of antecedent conditions and performance. Academy of Management Journal, 50(5), 1217-1234.

2. Carte, T. A., Chidambaram, L., \& Becker, A. (2006). Emergent leadership in selfmanaged virtual teams: A longitudinal study of concentrated and shared leadership behaviors. Group Decision and Negotiation, 15(4), 323-343

3. Colbert, F. (2003). Entrepreneurship and leadership in marketing the arts. International Journal of Arts Management, 6(1), 30-39

4. Drucker, Peter F. 1996. Innovation and entrepreneurship Practice and Based. Jakarta: Erlangga

5. Frink, D. D., Robinson, R. K., Reithel, B., Arthur, M. M., Ammeter, A. P., Ferris, G. R., Kaplan, D. M., \& Morrisette, H. S. (2003). Gender demography and organization performance. Group \& Organization Management, 28, 127-147.

6. Goolsby, Jerry R. 1992. A Theory of Role Stress in Boundary Spanning Positions of Marketing Organizations. Formal of the Academy of Marketing Science, 30 (2), 155-16

7. Greenberg-Walt, C.L. \& Robertson, A.G. 2001. The Evolving Role of Executive Leadership. In Bennis, Warren G., Spreitzer, retchen M. \& Cummings, Thomas G. (eds.). The future of leadership: today's top leadership thinkers speak to tomorrow's leaders. San Francisco: Jossey-Bass, pp. 139-157.

8. Hiller, N. J., Day, D. V., \& Vance, R. J. 2006. Collective enactment of leadership roles and team effectiveness: A field study. The Leadership Quarterly, 17(4) 387-397

9. Hitt, M. A., \& Ireland, R. D. 2000. The intersection of entrepreneurship and strategic management research. In D. L. Sexton \& H. Landstrom (Eds.), The Blackwell handbook of entrepreneurship. Oxford, UK: Blackwell

10. Hoch, J. E., \& Dulebohn, J. H. 2013. Shared leadership in enterprise resource planning and human resource management system implementation. Human Resource Management Review, 23, 114-125

11. Holmberg, K. \& Söderlind, E. 2004. Leda genom att dela: Om delat ledarskap i praktiken. Lidingö: Navigator dialog.

12. Hunt, J. and G.E. Dodge. 2000. Leadership déjà vu all over again. The Leadership Quarterly Review, 11 (4), pp. 435-458.

13. ICCA. Statistics. Report. 2014. International Congress and Convention Association ... Asia Pacific \& Middle East rankings: number of meetings per country.

14. Ishikawa, J. 2012. Transformational leadership and gatekeeping leadership: The roles of norm for maintaining consensus andshared leadership in team performance. Asia Pacific Journal of Management, 29:265-283.

15. Jackson, S. E., Hitt, M. A., \&Denisi, A. S. 2003. Managing knowledge for sustained competitive advantage: Designing strategies for effective human resource management. San Francisco: Jossey-Bass.

16. Matsumoto, D., Kudoh, T., \& Takeuchi, S. 1996. Changing patterns of individualism and collectivism in the United States and Japan. Culture and Psychology, 2, 77-107

17. O'Toole, J., Galbraith, J., \& Lawler, E. E. (2002). When two (or more) heads are better than one: The promise and pitfalls of shared leadership. California Management Review, 44(4), 65-83.

18. Pearce, C.L., \& Barkus, B. 2004. The future of leadership: Combining vertical and shared leadership to transform knowledge work. The Academy of Management Executive, 18(1), 47.

19. Pearce, C. L., \& Conger, J. A. (2003). All those years ago: The historical underpinnings of shared leadership. In C. L. Pearce \& J. A. Conger (Eds.), Shared Leadership: Reframing the hows and whys of leadership.

20. Potensi Industry MICE Indonesia. 2015. Warta Ekspor DJPEN/MJL/002/07/2011 Edisi: Juli. 
21. Pulkkinen, L. 1996. Female and male personality styles: A typological and developmental analysis.

22. Richard, O. C. 2000. Racial diversity, business strategy and firm performance: resource based view. Academy of Management Journal, 43, 164-177.

23. Richard, O., McMillan, A., Chadwick, K., \& Dwyer, S. 2003. Employing an innovation strategy in racially diverse workforces. Group \& Organization Management, 28, 107-126.

24. Robbins, S. P. and Coulter, M. 2007. Management (9th Ed.). London: Prentice-Hall

25. Rosen, J. M. 1999. Diversity on boards increases. New York Times, p. 3.7

26. Sally, D. 2002. Co-leadership: Lessons from Republican Rome. California Management Review, 44(4), 84-99

27. Seebaluck, V., Naidoo, P., and Ramseook-Munhurrun, P. 2013. Meetings, Incentives, Conferences and Exhibitions as a Tourism Development Strategy in Mauritius. Jurnal.

28. Sivasubramaniam, Murray, Avolio, \& Jung (2002) A Longitudinal Model of the Effects of Team Leadership and Group Potency. Group Performance Journal of Leadership \& Organizational Studies 17: 335-350, first published on June 7,

29. Small, E.E. \& Rentsch, J. R. 2010. Shared leadership in teams: A matter of distribution. Journal of Personnel Psychology, 9(4), 203-211.

30. Solimun. 2011. Multivariate Analysis Structural Equation Modelling (SEM) Lisrel \&Amos. Faculties MIPA, University of Brawijaya Malang.

31. Spisak, Michael J., O'Brien, Nigel, Nicholson, Mark Van Vugt. 2015. Niche Construction And The Evolution Of Leadership. Academy of Management Review, Vol. 40, No. 2, 291-306

32. Sugiyono. 2009. Business Research method, Eds 10. CV. Alfa beta, Bandung

33. White, G. L., \& Smith, K. H. (2010). Leadership characteristics and team outcomes in the development of a marketing web page. International Information Management Association, 99-116.

34. Wiklund, J., \& Shepherd, D. (2005). Entrepreneurial orientation and small business performance: A configurational approach. Journal of Business Venturing, 20, 71-91.

35. World Economic Forum (WEF), 2015 The Global Competitiveness Report 2015-2016: Full Data Edition is published by the World Economic Forum within the framework of the Global Competitiveness and Risks Team World Economic Forum

36. Worley, C. G., \& Lawler, E. E. (2006). Designing organizations that are built to change. MIT Sloan Management Review, 48(1), 18-23.

37. Yusof, A.A, Perumal, S. and Pangil, F, (2005), Principles of Entrepreneurship, Prentice Hall, Kuala Lumpur.

38. Zhou W. (2013) Is Informational Diversity Really Informational? An Investigation of What and When in Entrepreneurial Team. Journal of Marketing Development and Competitiveness vol. 7(3) 